\title{
THE PREVALENCE OF STAPHYLOCOCCUS AUREUS IN URINE POLLUTED ENVIRONMENT WITHIN DELTA STATE POLYTECHNIC OZORO
}

Okobia B. U*. and Orogu J.O.

\author{
Department of Science Laboratory Technology, Delta State Polytechnic Ozoro, Delta State, Nigeria
}

\section{Email- joshuaorogu4@gmail.com}

\begin{abstract}
The prevalence of Staphylococcus aureus in urine polluted environment was carried out to evaluate bacteria in urine in polluted environment in Delta State Polytechnic Ozoro, Delta State. Sixteen (16) different sites in the institution were used as the sampling points. The sites used are the undesignated areas for urine discharge. All samples were analyzed in the laboratory. Six (6) bacterial species were obtained; Staphylococcus aureus, Corynebacterium spp., Bacillus spp, Streptococcus spp., E. coli, and Klebsiella spp. The total heterotrophic plate count ranges from $1.8 \times 10^{3} \mathrm{CFU} / \mathrm{ML}$ to $2.13 \times 10^{4} \mathrm{CFU} / \mathrm{ML}$. Staphylococcus aureus have the highest percentage occurrence of $27.27 \%$ while Corynebacterium spp. Klebsiella spp. has the least percentage occurrence of $9.09 \%$. The public health implications of persistence urination in public soils as potential source of pollution to man and plants cannot be overemphasized.
\end{abstract}




\section{INTRODUCTION}

The soil environment includes viable plants (roots), animal and microorganism that in the pores spaces and are attached to the geological materials. (Dada and Aruwa 2014) opined that soil organic and inorganic matter is determinants of soil fertility and they also aid the proliferation of various soil micro flora which in turn play vital roles in the maintenance of the nutritional balance and geochemical cycles of the soil. Some species of bacteria thrive on different food sources and in different micro-environment in the soil (Dada and Aruwa 2014).

Despite soil being the habitat for the majority of earth's terrestrial species, far less attention has been paid to understanding maintenance of soil biodiversity until recently as pointed out by (Wardle 2002). Now, there is a growing interest in the below ground biodiversity, largely as a rescue of advances in technologies that enable more ready characterization of these below ground diversity (Blaxter and Floyd, 2003; Young and Crawford, 2004) and also because of the increasing recognition among ecophysiologists that soil biota play key roles in eco system functioning, especially organic matter turnover, nutrient mineralization (Horper et al., 2000; Wardle, 2002: Heimsbergen et al., 2004) and material flow through the ecosystem.

Urine is the pale yellow fluid produce by the kidneys and it contain urea, uric acid, minerals, chloride, nitrogen, sulphur, ammonia, copper, iron, phosphate, sodium, potassium, manganese, carbolic acid, calcium, sails; vitamins $A, B, C$ and $E$;
Enzymes hipphric acid, creatinine, as well as kctose. Other sugars are sometimes excreted in urine, if their concentration in their body is high. Urea is abundant in the urine of humans and other mammals (Dranget, 2000). The $\mathrm{PH}$ of urine range between 4 - 8 .

Urine is a filtered produce of kidney which contains only low molecular weight substances and at excretion the $\mathrm{PH}$ is normally around 6 but can vary between 4.5 and 8.2 (lentner et al., 2011). It was further shown by lentner that of the Nitrogen constituent of urine $75-90 \%$ is excreted as urea and the remainder as ammonium and creatinine. In the presence of increase, urea is quickly degraded to ammonium and carbon dioxide and the hydroxide ions produces will invariably increase soil PH from $9-9.3$ and this usually occur within hours of deposition (Jonssen et al. 2000). But the continual deposition of the soil because the conversion of ammonium $\left(\mathrm{NH}_{4}\right)$ to nitrate $\left(\mathrm{NO}_{3}\right)$ involves release of protons, thereby promoting acidity.

In Nigeria, urine deposition in public places go unchecked and has become a menace, a close examination of such soil macrocosm reveals patchiness of soil, obvious discoloration, purget ammonical smell (per comm.). There is therefore the need to establish the impact of human urine deposition on soil biota.Earlier report had describes human urine as non-toxic except when mixed with faeces and other organic compounds in septic tank (Dedeke, 2011). There the need to establish the impact of human urine 
deposition on soil and soil biota cannot be over emphasis.

\section{Materials and Methods Study Area}

This research was conducted in Ozoro, Delta State of Nigeria. Ozoro is the local Government headquarters of Isoko North Local Government of Area Delta State. The people are Isoko speaking and hospitable. Their main activities are food crop, farming accompanied by some hunting. They are also engaged in trade of food crop for cash to meet the other basic house hold needs. The region experience higher rainfall and humidity most of the year.

\section{Sample Collection}

Urine contaminated soil sample used in this study were collected from sixteen different sites in the institution. The sites used are the undesignated areas for urine discharge. The sites are the soil area noted for frequent urine discharge. The samples were dispensed in an EDTA container and then brought to the laboratory.

\section{Materials}

Commercially available nutrient agar was used in the study. The media was prepared according to manufacturer's instruction. The microbial loads of various groups of bacterial species were determined using the culture techniques involving different cultural media. The different soil samples were analyzed for the microbial diversity as described earlier in the sample collection. Bioloads were determined after decimal serial dilutions.

\section{Method}

Pure bacterial isolates were identified based on their characteristics such as morphology, microscopy, staining and capsule staining methods. The samples were analyzed for fungal isolates or sabouraud Dextrose Agar on establishment of growth after 4 days of incubation at room temperature, the plates were carefully examined and distinct growths were sub-cultured on fresh medium for purity. The fungal were indentified on the basis of their cultural characteristics and microscopy with reference to the methods describes by Barnett et al (2000).

\section{Characterization and Identification of Isolates}

Discrete colonies that developed after incubation were subcultures to obtain pure culture which were stored at $4^{\circ} \mathrm{C}$ and used subsequently for microscopic characterization and biochemical analysis. The distinct colonies that develop in the pure cultured plates were observed for the morphological and cultural characteristics, shapes, color of bacterial on the media were observed and recorded.

\section{Gram Stain}

The gram stain was carried out on 24hours culture. A bearer of each of the bacterial isolates was made on clean grease free slide and heat fixed using flame. Crystal violent stain $(0.3 \% \mathrm{~W} / \mathrm{O})$ was added and allowed to stand for 1 minute. The stain was washed off with distilled water. lodine $10.4 \%$ W/O), mordant was added and allow to stand for 50 seconds before rinsed off with distilled water. Ethanol (95\% W/O), a decolourizer was then added and allow to stand for 30 seconds before being rinsed off with distilled water and then counter stained with the secondary stain, safranin $(0.4 \% \mathrm{~W} / \mathrm{O})$ was allowed to stand for 1 
minute. This was then washed off with distilled water and allowed to dry. The stained smear was then observed under the microscope using oil immersion lens magnification (X100).

\section{Biochemical Test}

\section{Indole Test, Motility Test}

The test organism was inoculated with broth that contains tryptophan and incubates at $37^{\circ} \mathrm{C}$ for 48 hours. The $2 \mathrm{ml}$ of the broth suspension was transferred to another test tube under aseptic condition. About $0.5 \mathrm{ml}$ of kovac's reagent was added to the broth. The mixture was shaken properly to ensure a thoroughly mixing and then observed for colour reaction. A positive result was indicated by a pink coloured ring round the interface between the broth suspension and alcohol reagent which rose to the surface.

\section{Oxidaze Test}

A piece of glass rod was used to remove a colony of the test organism and was smear on the filter paper which was placed on a petri dish and 3 drop oxidize reagent was added. A positive result was indicated by aVI. blue-purple colour, while no blue-purple indicated negative.

\section{Catalase Test.}

Three (3) $\mathrm{ml}$ of the hydrogen peroxide solution was pour into a test tube then colonies were removed and immerse in the hydrogen peroxide solution using a sterile stick. Active babbling shows positive catalyst test. While non active babbling shows negative catalyst.

\section{Citrate Test}

Simmons agar was prepared in a test tube and sterile straight wire was used to break the slope with a saline suspension of the test organism. It was incubated at $370^{\circ} \mathrm{C}$ for 48 hours.13yardbluecolour show positive citrate while no change in colour shows negative citrate test.

\section{v. Glucose Test}

The test organism was inoculated with broth medium that contain bromocresol contain purple. An invents Durham tube is kept submerged in it. A color change to yellow and gas accumulates in Durham tube indicate fermentation for the glucose and acopogenic whole colour changes to yellow bur no gas accumulate in Durham tube indicate fermentation for glucose and anaerogenic. And colour of broth does not change indicated non fermentation for the glucose.

\section{Lactose Test}

Sterile inoculating tool is used to pick colonies of the test organisms and was immersed into a test tube that contains phenol. Colour changes to yellow indicate a positive test, while whole colour changes to pink indicate a negative test. 
Results and Discussion

Results

Table 1: The identification of Isolates

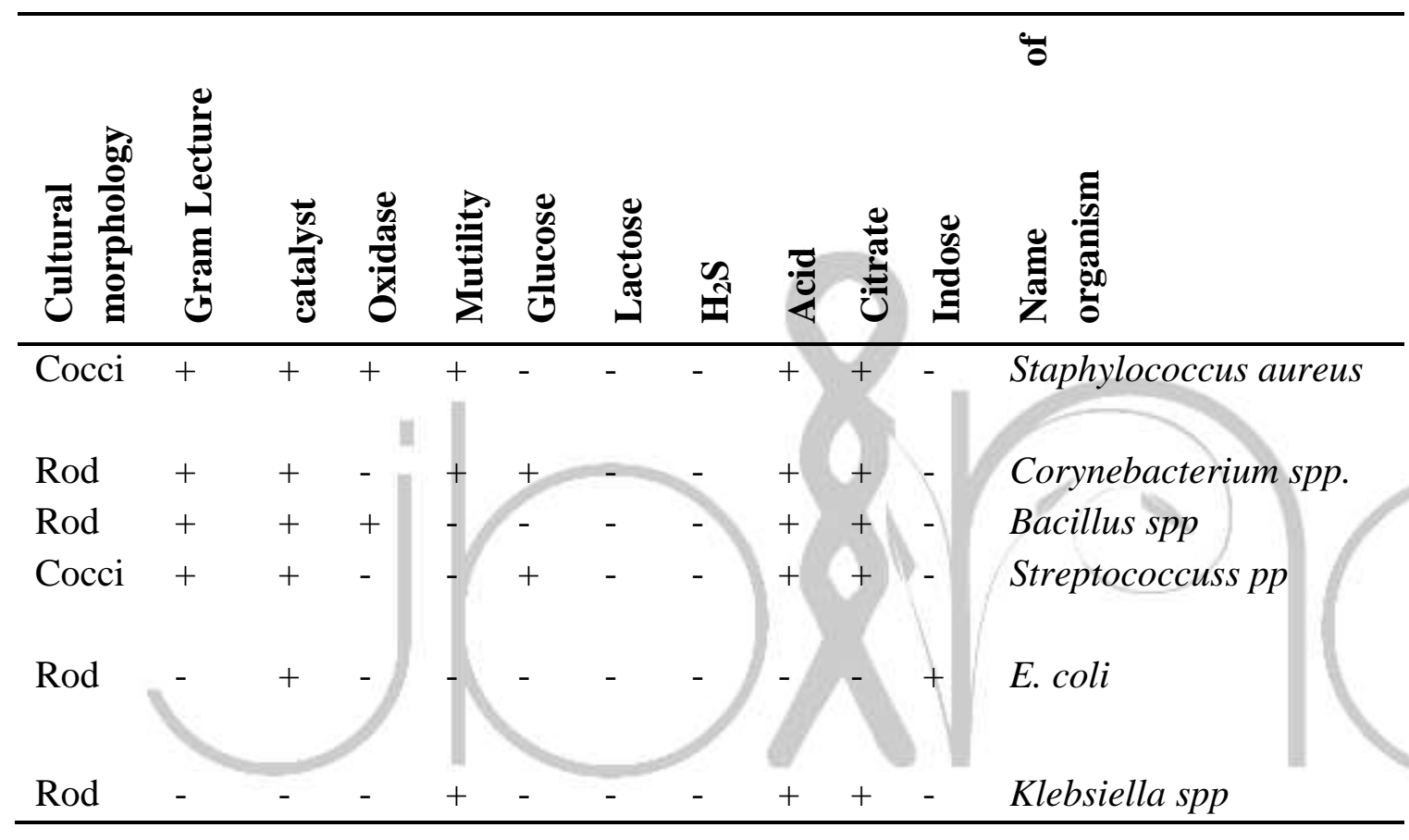

$$
\begin{aligned}
\mathrm{KEY}+ & =\text { Positive } \\
- & =\text { Negative }
\end{aligned}
$$

Table 2: The Heterotrophic Bacterial Counts of Urine Samples from Different Sites.

\begin{tabular}{ll}
\hline Samples & Bacterial Count \\
\hline A & $1.8 \times 10^{4}$ \\
B & $1.00 \times 10^{4}$ \\
C & $1.19 \times 10^{4}$ \\
D & $1.28 \times 10^{4}$ \\
E & $2.13 \times 10^{4}$ \\
F & $1.45 \times 10^{4}$ \\
G & $1.27 \times 10^{4}$ \\
H & $1.71 \times 10^{4}$ \\
\hline
\end{tabular}

2021 July Edition |www.jbino.com | Innovative Association 


\begin{tabular}{ll}
\hline $\mathrm{I}$ & $1.18 \times 10^{4}$ \\
$\mathrm{~J}$ & $1.60 \times 10^{4}$ \\
$\mathrm{~K}$ & $1.50 \times 10^{4}$ \\
$\mathrm{~L}$ & $1.37 \times 10^{4}$ \\
$\mathrm{M}$ & $1.8 \times 10^{3}$ \\
$\mathrm{~N}$ & $2.5 \times 10^{3}$ \\
$\mathrm{O}$ & $2.2 \times 10^{3}$ \\
$\mathrm{P}$ & $9.6 \times 10^{3}$ \\
\hline
\end{tabular}

Table 3: Percentage Occurrence of Bacteria Isolates

\begin{tabular}{lll}
\hline Isolates & $\begin{array}{l}\% \text { Occurrence } \\
\text { Bacteria }\end{array}$ \\
\hline Staphylococcus aureus & 27.28 \\
Corynebacterium spp. & 9.09 \\
Bacillus spp. & 18.18 \\
E. coli & 18.18 \\
Streptococcus spp. & 18.18 \\
Klebsiella spp. & 9.09 \\
Total & 100 \\
\hline
\end{tabular}

\section{Discussion}

Different colonies were observed at the end of the procedure necessary for the isolation and identification of bacterial associated with urine. The bacterial present in samples of urine were identifies bases on their culture, morphological and biochemical characteristics. The characterization and the identification of the bacterial isolates are shown in table 1.

The occurrence of the bacterial isolate from the urine samples obtained from different sites in the institution is shown in table 1. From the entire urine sample obtained from sixteen different spots, Staphylococcus aureus was the most prevalent recording with $27.28 \%$ while Klebsiella spp and Corynebacterium spp. was the least prevalent recording with

$9.09 \%$. The value of heterotrophic bacteria counts of the urine sample from the samples in Ozoro Delta during the period of study is presented in table 3.

The majority of microbial population is found in the upper 6-12 inches of soil and the number decrease with depth (Bridge and Spooner, 2001). The number and kinds of organism found in soil, matter, temperature, moisture and aeration. The presence of bacteria in the urine without the symptoms of an infection is quite common and has been identified as a contributor to antibiotic misuse, which promotes resistance. Between $65 \%$ and $90 \%$ of urine tract information's in children are caused by Escherichia coli. Other pathogens include Klebsiella species, 
J.Bio.Innov 10(4), pp: 1001-1008, 2021 | ISSN 2277-8330 (Electronic)

Orogu \& Okobia

Proteus species, Pseudomonas aeruginosa and Enterococcus species (Nir, 2005).

\section{Conclusion and Recommendations}

\section{Conclusion}

Urine contaminates soils are public health hazards which are avenues for transmission of infection from one person to another. Poor hygienic habits, overpopulation and overstretched facilities encourage indiscriminate urination in public places. The practice can either increase or decrease the microflora of urine contaminates soils. An increase in microbial load in such environments may result in increases probability of contracting opportunistic infections. Available toilet facilities within the study area fell far below that requires for the ever growing population of students.

\section{Recommendations}

1. The provision of more and adequate toilet facilities should be provided by the government.

2. The practice and enforcement of basis sanitary rules would help prevent unnecessary deaths and protects the health of millions of persons.

3. Water closet toilet type and/or mobile toilet should be made available.

\section{REFERENCES}

Arthur C. Enytor; john Edward HII (2006); 25" Textboom of medial physical physiology (http://books.google.com/books?id=STZHA QAAIAAJ)

Blaxfer, M. and flug, R. (2003). Molecular taxonomies for b. Adiversity survey; already a reality. Time in Eol. And Evol. 18:268-269
Bridge, P, Spinner B (2001) soil fingi: diversity and defection. Plant as soil 232 (1.2): 147154

Carrel. D.T.; peferson, C.M. (eds.) 2010) artificial insemination: intracterine insemination

31.3.1.2Evandotropics" (http://books.google .com//id=1cBEheinfV cc8pj=PA4898\&jpg= $\mathrm{PA} 489 \& \mathrm{dg}=$ urine-

derived+gnadufnpins $=\mathrm{v}=$ onepage $\& 9=$ urined erived \%20gsnadotropins \& $\mathrm{f}=$ false)

Cheese brough, M. (2006) District laboratory practice in tropical countries-cambridge university press, uk. Second low price edition. Soil fungi: Diversity and detection. Plant and soil 232 (1-2):147-954

Dada, E.O and Aruwa, C.E (2014). Micro organisms associations with urine conterminated soils around fecture theaters inn Federral university of Technology, Akure, Nigeria. International journal of Applied micro-biology and Biotechnology, 2:79-85

Dragnet $\mathrm{Re}$ use- the ultimate urine -diverting trigger to protect gums water guchty and fertilizer urban agriculture. IN:chrew I., Rigneband, G. schla, G. ar Schril, o. (eds), water saitation and health. Processing of the informal conference, Ban Else., Germany 24-28 November, 1998. IWA publishing London, uk, Pp. 275-280

Frazier W.C and wesh of D.C (1998) Food mawbytory 4th editon. Tal Mc Grew holi:india p4-27

Hersbergen, D.A., Berg, M.P., lorean, M., van Hal.J.R., Faber, J.H and verhoef, H.A. (2004) B. adversity effect or soil process explained by in the specific funtural dissimilarity. Science 306: 1019-1020 
Hilt, Evan E; ; Kathleen Mckinsley: Maghan M. pearce Amy B. Rosenfeld: Michael J. z:llivx; Elizabeth R. Mueller; linds Brubaker: xiaown aa:Alam J. wrife; panl C, Schreckenberge, (2013) journal of clinical Microbiology 5 2(3) 871-876

Hogland, C., Ashbill, N and stransform,7.A (2002) Micheal rise assessment of source separate urine used in Agriculture. Waste management resource 20: (62-171.

Logan N.A. (2000)- Bacillns arthrcis, Bacills cerens, and other aerobic end, sporeforming bactery in:Boriello S.P., Murrey P.Rand franc G. (EO), Tuploy and Wilson Microbiology and microbic infections Bacterialogy (2): 922-952

Josson $H$, vinners $B$, Hogland $C$., stenstion TA, Da hammar $G$ (2000) Recycling source seperates human, Sweden

Martin Hernandiz E. Aparicio lopez C, Alveare2 calatayus .g, Geraa Herrera MA.(2001). Review 2008-12.25

Mentined by an inferiewee in lorax the soughanter, a 2004 documentary film.' Micheal T. Madiga; Thamos D. Brock (2009). Brockbiology of micro-organisms (http://books.google.com/books?id=STZHA QAAIAAJ)

Olutiola P.O., Famurewa o.\& Sonntag H.G. (1991). AN. Introduction for general microbiology: A pratical approach: Heldol berger Verlagsansalt and Drunkere $\mathrm{GmbH}$. Heldelberg. P.267
Rose. C., parker, A., defferson, B;. cartmell, E. (2010). The charraterization of faeces and urine: A review of the literature to inform Advances Treatment Technology" (h//ps://www.ncb:nlm:h.gov/pmc/article/ pmc 4500995). Critical Review in environmental science and Technology. 45 (17): 1827-1879

Stefan Gafes: Max la Review-Hedrick (15 march 2006) Gastronant: advancetures I food for thernatic, the foulhardy. And the brave

(https://books.google.crm/books?id=disxxga Gw9uc\&pj=PA87

Wardle, O,A (2002). Comuities and Ecosystems; linking the above ground and below ground component Princeton onversly press

Yang, P.J.; pham, J., Hu.DL (26 june 2014). A duration of urination does not change with body size (https.//www.ncb.nlminil.gov/pnc/articles/ pmc4143032) proceedings of the Natural Academy of Sciences 111 (33); 1193211937

Young. I.M and Crawford, J.W (2004). Interactions and self organization in the soil microb complex. Science. 304: 1654-1637 